\title{
Evaluation of Acute and Sub-acute Oral Toxicity Effect of Aquilaria malaccensis Leaves Aqueous Extract in Male ICR Mice
}

\author{
Nur Hidayat Che Musa, Haniza Hanim Mohd Zain*, Husni Ibrahim, and Nor Nasibah Mohd Jamil \\ Department of Biology, Faculty of Science and Mathematics, Universiti Pendidikan Sultan Idris, \\ 35900 Tanjong Malim, Perak, Malaysia
}

\begin{abstract}
The study was conducted to investigate the acute and sub-acute toxicity effect of Aquilaria malaccensis leaves aqueous extract (AEAM) towards male ICR mice in terms of body weight, relative organ weight, mortality rate and sperm parameters. In acute toxicity study, a single dose at of $2000 \mathrm{mg} / \mathrm{kg}$ was performed. In sub-acute toxicity study, the mice were received normal saline (control group), 50, 100, 150, 200, 500 , or $1000 \mathrm{mg} / \mathrm{kg}$ of AEAM orally for 21 days of treatment. In sub-acute toxicity study, the number of abnormal sperm were significantly decreased in AEAM 100, 150, 200, 500, and 1000 when compared to the control group. While, the motility of sperm were found to be significantly increased in AEAM 100, 150, 200, and 1000 as compared to the control group. No mortality was recorded in the control group and treated groups in both toxicity studies except for one mouse from AEAM 1000 group. However, the mild sedative effect in terms of the tendency to sleep was clearly noticeable in both toxicity studies. Results indicated that the AEAM can be one of the useful alternative medicine to enhance fertility rate by increasing healthy sperm production.
\end{abstract}

Keywords - Aquilaria malaccensis, Aqueous extract, Acute toxicity, Sub-acute toxicity

\section{Introduction}

The growing popularity and market interest for the plant-based drugs used among Malaysian are undeniable specifically in improving male fertility and this situation may bring to a dynamic transformation in the modern world. ${ }^{1}$ The World Health Organization (WHO) defined infertility as the state in which a couple whom fail to get children after one year of regular unprotected intercourse. ${ }^{1}$ The percentage of couples whom fail to get children within one year is about $25 \%, 15 \%$ of whom look for medical treatment to heal infertility problem and under $5 \%$ of the couple remain unwillingly childless. ${ }^{2}$ Infertility problem has been affected both men and women over the world. Recently, the sperm evaluation is very vital in investigating the fertility status in male. ${ }^{3}$ The reduction in the number of sperm cells, low motility rate, and increase in malformation of sperm cells are the primary causes of infertility problem in the male. ${ }^{4}$ Some plant species have been used as fertility enhancing in traditional medicines of various countries such as Psidium guajava, ${ }^{5}$ Eurycoma

\footnotetext{
*Author for correspondence

Associate Prof. Dr. Haniza Hanim Mohd Zain, Department of Biology, Faculty of Science and Mathematics, Universiti Pendidikan Sultan Idris, 35900 Tanjung Malim, Perak, Malaysia.

Tel: +6015-48797204; E-mail: haniza@fsmt.upsi.edu.my
}

longifolia, ${ }^{6,7}$, Lunasia amara, ${ }^{8}$ Gynura procumbens, ${ }^{9}$ Chlorophytum borivilianum, ${ }^{10}$ Phaleria macrocarpa, ${ }^{11}$ and Hibiscus sabdariffa. ${ }^{12}$ Another potential plant for fertility purpose that still not investigate belongs to the genus of Aquilaria which is Aquilaria malaccensis. This species also known as agarwood and the leaves of this plant are frequently used in folk medicine in many countries for the promotion of good health and treatment of many ailments. Many previous studies have been performed on the effect of different species of the agarwood leaves extracts as anticancer agent, ${ }^{13}$ Alzheimer's disease drug, ${ }^{14}$ therapeutic laxative agent, ${ }^{15-16}$ antipyretic and antiinflammatory, ${ }^{17}$ antimicrobial, ${ }^{18,19}$ and anti-hyperglycemic activity. ${ }^{20}$ However, there are no studies have been reported till date on agarwood leaves extracts that may act as a supplement to cure infertility problem in men scientifically although it has been used traditionally for years.

Nowadays, there is increasing concern about the safety of medicinal plants and their ability to produce toxicity and adverse effects to the consumers. Currently, the finding of the acute and sub-acute toxicity studies on plant based drugs and its preparation becomes compulsory to be practiced by researchers around the world due to the increase of sureness in plant based drugs safety for human use. ${ }^{21,22}$ Toxicity studies are very helpful in 
providing the information that extremely useful as the main precursors to guide the correct decision making either a new drug should be adopted for clinical used or not and fortunately, to date, no drug is utilized clinically without its clinical trials and toxicity studies. ${ }^{23}$

Thus, the present study is important to provide scientific support for its purported folkloric usage since there is no scientific information available in the literature on any systemic toxic effect for single and repeated doses of $A$. malaccensis aqueous crude extract (AEAM). A wide variety of parameters is monitored, such as cage-side observation for irregular signs, body weight, relative organ weight, mortality number, and sperm evaluation.

\section{Experimental}

Plant materials - Aquilaria malaccensis with herbarium number NHM002 was collected from Agarwood Al-Hilmi plantation in Behrang, Perak, Malaysia in November 2015. Species was identified by Associate Prof. Dr. Fatimah Mohamed from Biology Department, Universiti Pendidikan Sultan Idris and deposited to the Herbarium of Universiti Pendidikan Sultan Idris.

Plant sample extraction-The fresh leaves of $A$. malaccensis were collected from Agarwood Al-Hilmi plantation in Behrang, Perak, Malaysia. The leaves were washed, air dried, and ground using electrical grinder to form a fine powder. $800 \mathrm{~g}$ of the powder was macerated in $8 \mathrm{~L}$ of distilled water for $24 \mathrm{~h}$ at room temperature with occasional stirring. The mixtures were filtered using cloth filter at room ${ }^{24}$ and the filtrate obtained were oven dried at $55^{\circ} \mathrm{C}$ for 48 hours, ${ }^{25}$ followed by freeze drying for $72 \mathrm{~h}^{26}$ The brown crude extract obtained was stored at $-20{ }^{\circ} \mathrm{C}$ prior to further use.

Experimental animals - The experiment was performed on healthy male ICR mice of 12 to 14 weeks old and body weight of $34 \pm 6 \mathrm{~g}$. All methods that applied in this study was done under proper research ethics and care that was approved by University Pendidikan Sultan Idris research ethics committee. Mice were randomly divided into 2 groups and 7 groups comprising of 5 animals each for acute and sub-acute toxicity studies respectively. The animals were housed maximum 5 mice in each polypropylene cage under standard animal housing conditions with controlled lighting ( $12 \mathrm{~h}$ dark-light cycles) and temperature $\left(25 \pm 2{ }^{\circ} \mathrm{C}\right)$. During the entire experimental period, the animals were provided with food and water $\mathrm{ad}$ libitum. The animals were allowed to acclimatize for 5 days before the experiment started. ${ }^{27}$

\section{Toxicological evaluation}

Acute oral toxicity study - For acute toxicity study, a single dose was performed at $2000 \mathrm{mg} / \mathrm{kg}$ as implemented by previous study. ${ }^{28}$ The aim of this study is to investigate the single oral toxicity effect of the crude extract from $A$. malaccensis leaves towards ICR male mice. Ten healthy mice were randomly selected and divided into two groups. Feeding was done using plastic syringes attached to ball-tipped stainless steel feeding needle. The control group received an equal volume of normal saline orally. The general behaviour of the mice was continuously monitored and observed using CCTV video camera after dosing, periodically during the first $24 \mathrm{~h}$ and then daily thereafter, for a total of 14 days. All animals were weighed on $0,7^{\text {th }}$, and $14^{\text {th }}$ days and were observed for any abnormal behaviour symptoms and mortality. Animals were sacrificed under ether anesthesia at the end of the experiment.

Sub-acute oral toxicity study-Repeated dose oral toxicity study was carried out according to OECD Guideline $407 .{ }^{29}$ Thirty five adult male mice were divided into 7 groups and treated with AEAM using plastic syringes attached to ball-tipped stainless steel feeding needle daily for 21 successive days (Table 1). The administration volume was $10 \mathrm{~mL} / \mathrm{kg}$ b.w of the animal. ${ }^{27}$ The quantity of the crude extract was calculated based on the body weight of the animal and dissolved in distilled water before administered directly to the mice. ${ }^{30}$ All the animals were closely observed using CCTV video camera via cage-side observation during the first $30 \mathrm{~min}$ after

Table 1. The different doses of aqueous extract for experimental groups

\begin{tabular}{ll}
\hline \hline \multicolumn{1}{c}{ Group } & \multicolumn{1}{c}{ Treatment } \\
\hline Control & Mice received $10 \mathrm{ml} / \mathrm{kg}$ body weight of normal saline $(\mathrm{n}=5)$ \\
AEAM 50 & Mice received $50 \mathrm{mg} / \mathrm{kg}$ body weight $/$ day crude extract $(\mathrm{n}=5)$ \\
AEAM 100 & Mice received $100 \mathrm{mg} / \mathrm{kg}$ body weight $/$ day crude extract $(\mathrm{n}=5)$ \\
AEAM 150 & Mice received $150 \mathrm{mg} / \mathrm{kg}$ body weight $/$ day crude extract $(\mathrm{n}=5)$ \\
AEAM 200 & Mice received $200 \mathrm{mg} / \mathrm{kg}$ body weight $/$ day crude extract $(\mathrm{n}=5)$ \\
AEAM 500 & Mice received $500 \mathrm{mg} / \mathrm{kg}$ body weight $/$ day crude extract $(\mathrm{n}=5)$ \\
AEAM 1000 & Mice received $1000 \mathrm{mg} / \mathrm{kg}$ body weight $/$ day crude extract $(\mathrm{n}=5)$ \\
\hline
\end{tabular}


treatment, followed by observation during the first $4 \mathrm{~h}$ for mortality and sign of illness. Then, they were observed periodically for the next $24 \mathrm{~h}$ and once daily for the next 21 days. The animals were observed daily for the purpose of observing any abnormal signs including; changes in skin colour, fur, and eyes; respiratory effects; salivation; diarrhea; urination and sleepy symptoms. ${ }^{31,32}$ The number of mortality also recorded and calculated in percentage. Body weight $(\mathrm{g})$ of the mice was recorded on day 0 , day 7 , day 14 and day 21 by using electronic scale. The mortality rate in percentage also calculated in this study. ${ }^{22}$

Relative organ weight - At the end of the experiment, all the animals in both toxicity studies were sacrificed to obtain the relative organ weight. At day 15 (acute toxicity study) and day 22 (sub-acute toxicity study), the animals were sacrificed under ether anesthesia. Liver, kidney, testis and epididymis were carefully removed, free from adipose tissue, rinsed with normal saline, dried and weighed separately. The relative organ weight of each animal was then calculated using formula from previous studies. ${ }^{22,33}$

Sperm toxicity study - After sacrificed under ether anesthesia at the end of the experiment, all of the experimental animals were furthered with sperm evaluation that consists of sperm motility, sperm morphology and sperm count.

Preparation of sperm suspension for sperm parameters - Sperm were obtained from fresh epididymis of adult mice. The epididymis of each animal was removed and placed in a small clean petri dish containing $5 \mathrm{ml}$ of physiological $\mathrm{NaCl}$-solution $(0.9 \%)^{2}$ preheated to $37^{\circ} \mathrm{C} .{ }^{34}$

Sperm count - Epididymal sperm were counted by a modified method. ${ }^{35}$ Briefly, the epididymis was minced in $5 \mathrm{ml}$ of physiological saline $(0.9 \% \mathrm{NaCl})$ in petri dish. The sperm suspension obtained was mixed with $1 \%$ eosin $\mathrm{Y}$ in the ratio of $1: 1$. About $10 \mu \mathrm{L}$ of the sample was transferred to each counting chamber of the Neubaur haemocytometer and was allowed to stand for 5 minutes for sedimentation, then sperm were counted in the large four squares and expressed as sperm count in million using inverted microscope at $10 \mathrm{x}$ magnification.

Sperm motility - The motility of sperm was evaluated under $20 \mathrm{x}$ magnification of an inverted microscope. Approximately $10 \mu \mathrm{L}$ of the sperm suspension was transferred to a Neubauer's chamber. ${ }^{2}$ Sperm motility was categorized into "motile" or "non-motile". ${ }^{2}$ Non-motile sperm numbers were first determined, followed by counting of total sperm. Sperm motility was expressed as percentage of motile sperm from the total sperm counted. ${ }^{36}$
Sperm morphology - The sperm morphology was determined with slight modification ${ }^{37} .10 \mu \mathrm{L}$ of Eosin $\mathrm{Y}$ ( $1 \%)$ stain was added to $50 \mu \mathrm{L}$ of the sperm suspension and kept for 5 minutes. After that, $10 \mu \mathrm{L}$ of the sample was pippetted to sample injection area of the Neubauer improved disposable hemocytometer chamber and was air dried before observed under the microscope for changes in sperm morphology. The criteria were chosen for abnormality of sperm based on some previous studies., ${ }^{3,38,39}$ abnormalities recorded were; no hook, banana shape, pin head, bent head, coiled flagellum, bent flagellum, hairpin loop and bent flagellum. Two hundred randomly chosen sperm from each mice were evaluated using $40 \times$ magnification of the inverted microscope. Sperm morphology was expressed in percentage. ${ }^{40}$

Statistical analysis - All results were expressed in mean \pm SEM. Statistical analyses were performed using Student's t-test or one-way ANOVA was used followed by Tukey's test for parametric multiple comparisons between the control and the treatment groups. The values were considered significantly different when the $p$ value was less than $0.05(p<0.05)$.

\section{Result and Discussion}

Nowadays, there has been an increasing use of the medicinal plant as the alternative way for treatment of various diseases, but their toxicities and side effects are still poorly recognized. ${ }^{41}$ Therefore, toxicity studies must be done in order to verify the safety and effectiveness of plant medicine for human consumption. In the present study, water extract of $A$. malacensis leaves was used to test acute and sub-acute toxicity in terms of body weight, relative organ weight, mortality rate and sperm parameters.

Based on the acute toxicity findings, the median lethal dose $\left(\mathrm{LD}_{50}\right)$ value could not be determined, as $\mathrm{LD}_{50}$ describes only one end point that causes the death of 50\% of the tested animals. Thus, the results obtained in this study suggested that the $\mathrm{LD}_{50}$ of AEAM leaves is higher than $2,000 \mathrm{mg} / \mathrm{kg}$ body weight, as all animals survived and no mortality was found in the mice exposed to the highest concentration given throughout the experimental period (Table 2). A similar result was obtained in the administration of agarwood (Aquilaria crassna) young leaves crude ethanolic extract to the experimental animals. ${ }^{27}$ They found that there was no mortality observed after the administration of plant extract.

Table 2 showed that there was a significant difference in the body weights changes in acute toxicity study between the treated group and control group of mice on 
Table 2. Changes in body weight and mortality rate (\%) of single dose $(2000 \mathrm{mg} / \mathrm{kg})$ of $A$. malaccensis leaves extract on the body weight of mice for 14 days

\begin{tabular}{ccccc}
\hline \hline Treatment Groups & \multicolumn{3}{c}{ Body weight in grams (mean \pm SEM) } & \multirow{2}{*}{ Mortality rate (\%) } \\
\cline { 2 - 4 } & \multicolumn{1}{c}{ Day 0 } & Day 7 & Day 14 & 0 \\
\hline Control & $35.58 \pm 0.50$ & $35.95 \pm 1.09$ & $34.03 \pm 1.45$ & 0 \\
AEAM 2000 & $40.21 \pm 1.39^{*}$ & $38.11 \pm 2.05$ & $38.79 \pm 1.36^{*}$ & 0 \\
\hline
\end{tabular}

* The mean difference is significant at $p<0.05$ level $\mathrm{n}=5$ in each group

Table 3. Effects of single dose of $2000 \mathrm{mg} / \mathrm{kg}$ of $A$. malaccensis leaves extract on relative organ weights

\begin{tabular}{ccccc}
\hline \hline Treatment Groups & \multicolumn{4}{c}{ Relative organ weights in grams (mean \pm SEM) } \\
\cline { 2 - 5 } & Testis & Epididymis & Kidney & Liver \\
\hline Control & $0.65 \pm 0.07$ & $0.35 \pm 0.03$ & $1.42 \pm 0.07$ & $4.42 \pm 0.16$ \\
AEAM 2000 & $0.53 \pm 0.04$ & $0.34 \pm 0.02$ & $1.33 \pm 0.04$ & $4.85 \pm 0.32$ \\
\hline
\end{tabular}

* The mean difference is significant at $p<0.05$ level

$\mathrm{n}=5$ in each group

Table 4. Effects of single dose of $2000 \mathrm{mg} / \mathrm{kg}$ of A. malaccensis leaves extract on sperm parameters of mice given 14 days' treatment

\begin{tabular}{cccc}
\hline \hline \multirow{2}{*}{ Treatment Groups } & \multicolumn{3}{c}{ Sperm parameters (mean \pm SEM) } \\
\cline { 2 - 4 } & Sperm abnormality $(\%)$ & Sperm count $\left(10^{6} / \mathrm{ml}\right)$ & Sperm motility $(\%)$ \\
\hline Control & $43.57 \pm 0.73$ & $0.97 \pm 0.17$ & $49.02 \pm 1.86$ \\
AEAM 2000 & $44.02 \pm 0.59$ & $1.15 \pm 0.08$ & $58.38 \pm 1.90^{*}$ \\
\hline
\end{tabular}

* The mean difference is significant at $p<0.05$ level

$\mathrm{n}=5$ in each group

Table 5. Changes in body weight and mortality rate (\%) of mice following treatment with different doses of $A$. malaccensis aqueous leaf extract

\begin{tabular}{cccccc}
\hline \hline \multirow{2}{*}{ Treatment Groups } & \multicolumn{4}{c}{ Body weight $(\mathrm{g})$ (mean \pm SEM) } \\
\cline { 2 - 5 } Mortality rate (\%) \\
\cline { 2 - 5 } Control & \multicolumn{1}{c}{ Day 0 } & Day 7 & Day 14 & Day 21 & 0 \\
AEAM 50 & $33.74 \pm 0.53$ & $32.64 \pm 0.31$ & $32.85 \pm 0.37$ & $33.47 \pm 0.64$ & 0 \\
AEAM 100 & $34.34 \pm 0.21$ & $32.37 \pm 0.63$ & $31.77 \pm 0.71$ & $32.42 \pm 0.78$ & 0 \\
AEAM 150 & $35.40 \pm 0.59$ & $34.11 \pm 1.09$ & $34.16 \pm 1.24$ & $34.96 \pm 0.99$ & 0 \\
AEAM 200 & $34.61 \pm 0.64$ & $33.62 \pm 0.60$ & $31.67 \pm 0.21$ & $31.79 \pm 0.34$ & 0 \\
AEAM 500 & $39.28 \pm 0.96^{*}$ & $37.40 \pm 1.17 *$ & $35.45 \pm 0.68$ & $35.66 \pm 0.82$ & 0 \\
AEAM 1000 & $37.09 \pm 0.40^{*}$ & $33.16 \pm 1.39$ & $33.15 \pm 1.13$ & $32.71 \pm 0.89$ & 20 \\
\hline
\end{tabular}

* The mean difference is significant at $p<0.05$ level

$\mathrm{n}=5$ in each group

day 0 and day 14 . Basically, in acute toxicity study, the dose level of plant extract is considered to be toxic when it's caused $10 \%$ or more reduction in body weight of treated animals. ${ }^{42}$ Therefore, the present finding was confirmed that the treated mice which received AEAM 2000 was in safe condition because the reduction in body weight was less than $10 \%$ when compared to their initial body weight.

The relative organ weights of mice in acute toxicity study are presented in Table 3 . There were no significant differences observed in the relative organ weights of all organ in the treated mice as compared to control group. The administration of single dose of AEAM 2000 caused slightly increase in the percentage of abnormal sperm count, sperm count and the percentage of sperm motility in all treated groups as compared to the control group (Table 4). However, there were no significant differences found in sperm parameters except in sperm motility $(p<$ $0.05)$ when compared to the control group.

The changes in body weight and percentage of mortality rate of treated mice in sub-acute toxicity study are presented in Table 5. No mortality was recorded in control 
group and treated groups except for the treated group of AEAM 1000 (20\% mortality rate). There was a significant change $(p<0.05)$ in the body weight of treated mice receiving AEAM 150, 500 and 1000 (day 0) and AEAM 500 (day 7) as compared to control group (Table 5). This situation is probably due to the stress condition that might be obtained in the treated mice through force feed technique of AEAM that implemented in this study. Mice are a stress sensitive animal and quite difficult to cope and adapt with its unfamiliar daily routine. ${ }^{43}$ Therefore the slight reduction in body weight of mice in AEAM treated groups starting from day 7 to day 21 compared to their initial body weight on day 0 is probably due to this stress condition. This result is parallel with the finding from a previous study ${ }^{44}$ They reported that there was a change in body weight of treated mice for the repeated oral administration that received methanolic extraction of $A$. crassna leaves ( 800 and $8000 \mathrm{mg} / \mathrm{kg}$ b.w) starting from day 2 until the end of the experimental period when compared to the control. The earlier study ${ }^{43}$ also suggested that the reduction in body weight in mice are probably related to the reduction of its daily food intake due to the stress condition.

The results for sub-acute toxicity study of the relative organ weights of mice are summarized in Table 6 . There were no significant differences $(p>0.05)$ observed in the relative organ weights of all organ as compared to the control group. The organs weights are relatively sensitive indicators for particular organs in toxicity studies especially liver and kidney. ${ }^{45}$ The findings of the present study exposed that the internal organs like liver, kidney, testis and epididymis were not adversely affected by toxicity throughout the treatment. This finding also in agreement with earlier study ${ }^{45}$ that working on Calotropis gigantean, they found that there were no significant changes recorded in the internal organ weights of the treated animals when compared to the control group. Thus, they suggested that all of the treated animals that received $C$. gigantean extract had no effect on their normal growth and keep healthy throughout the experimental period.

Recently, phytochemicals that derived from plant have been drawing many interests among researchers due to its potential as natural alternatives to synthetic compounds that already available nowadays. ${ }^{46}$ The presence of various phytochemical constituent especially flavonoids in the medicinal plant is very beneficial because this constituents have androgenic effects that useful to stimulate the spermatogenesis by enhancing the production and development of mature sperm cell in man. ${ }^{47}$ The phytochemical constituents found by previous researchers in Aquilaria leaves extract are flavonoid glycosides, ${ }^{48}$ 2-(2- phenylethyl) chromenes, ${ }^{49}$ lignans ${ }^{50}$ and diterpenoids. ${ }^{51}$ Besides, the phytochemical constituents such as alkaloids, tannins, saponins, flavonoids, and terpenoids also are available in the Aquilaria leaves extract. ${ }^{13,52}$

The phytochemicals that derived from plant extract may contribute a huge benefit to consumer as a health supplement specifically as antioxidant agent. ${ }^{53}$ Generally, plant with antioxidant properties capable to suppress lipids peroxidation hence reduces the number of abnormal sperm. ${ }^{54}$ In this study, the presence of antioxidant for $A$. malaccensis plant leaves have not been examined, but from previous studies ${ }^{19,26}$ reported that the extraction of leaves from this species has natural antioxidant properties. Therefore, it can be said that the leaves extract of this plant probably contributes to the reduction of abnormal spermatozoids through a similar mechanism. This situation was confirmed when the present study found that there was a significant reduction in abnormal sperm count for treated groups of AEAM 100, 150, 200, 500 and 1000 as compared to the control group (Table 7). There were 7 types of abnormality being observed in all experimental groups such as no hook, amorphous head, pin head, bent head, coiled flagellum, hairpin loop, and bent flagellum

Table 6. Effects of repeated doses of $A$. malacensis leaves extract on the relative organ weights of mice given 21 days' treatment.

\begin{tabular}{ccccc}
\hline \hline Treatment Groups & \multicolumn{4}{c}{ Relative organ weights in grams (mean \pm SEM) } \\
\cline { 2 - 5 } & Testis & Epididymis & Kidney & Liver \\
\hline Control & $0.69 \pm 0.05$ & $0.42 \pm 0.02$ & $1.35 \pm 0.08$ & $4.21 \pm 0.26$ \\
AEAM 50 & $0.65 \pm 0.04$ & $0.40 \pm 0.01$ & $1.31 \pm 0.06$ & $4.64 \pm 0.19$ \\
AEAM 100 & $0.63 \pm 0.02$ & $0.45 \pm 0.03$ & $1.36 \pm 0.03$ & $4.32 \pm 0.24$ \\
AEAM 150 & $0.62 \pm 0.04$ & $0.37 \pm 0.04$ & $1.23 \pm 0.06$ & $4.41 \pm 0.36$ \\
AEAM 200 & $0.68 \pm 0.04$ & $0.39 \pm 0.02$ & $1.37 \pm 0.07$ & $4.32 \pm 0.20$ \\
AEAM 500 & $0.63 \pm 0.02$ & $0.35 \pm 0.05$ & $1.29 \pm 0.09$ & $4.91 \pm 0.25$ \\
AEAM 1000 & $0.67 \pm 0.02$ & $0.36 \pm 0.03$ & $1.23 \pm 0.09$ & $4.42 \pm 0.22$ \\
\hline
\end{tabular}

* The mean difference is significant at $p<0.05$ level

$\mathrm{n}=5$ in each group 
Table 7. Effects of repeated doses of A. malacensis leaves extract on sperm parameters of mice given 21 days' treatment

\begin{tabular}{cccc}
\hline \hline \multirow{2}{*}{ Treatment Groups } & \multicolumn{3}{c}{ Sperm parameters $($ mean \pm SEM) } \\
\cline { 2 - 4 } & Sperm abnormality $(\%)$ & Sperm count $\left(10^{6} / \mathrm{ml}\right)$ & Sperm motility $(\%)$ \\
\hline Control & $41.91 \pm 1.34$ & $1.08 \pm 0.17$ & $49.23 \pm 1.41$ \\
AEAM 50 & $40.33 \pm 1.24$ & $0.91 \pm 0.22$ & $50.55 \pm 1.67$ \\
AEAM 100 & $15.70 \pm 1.33^{*}$ & $1.36 \pm 0.28$ & $64.92 \pm 1.57^{*}$ \\
AEAM 150 & $26.52 \pm 0.89^{*}$ & $1.41 \pm 0.12$ & $63.57 \pm 1.10^{*}$ \\
AEAM 200 & $27.91 \pm 0.90^{*}$ & $0.94 \pm 0.13$ & $57.69 \pm 0.78^{*}$ \\
AEAM 500 & $30.97 \pm 0.76^{*}$ & $0.86 \pm 0.13$ & $50.80 \pm 0.85$ \\
AEAM 1000 & $34.66 \pm 0.81^{*}$ & $1.06 \pm 0.18$ & $56.11 \pm 1.71^{*}$ \\
\hline
\end{tabular}

* The mean difference is significant at $p<0.05$ level

$\mathrm{n}=5$ in each group
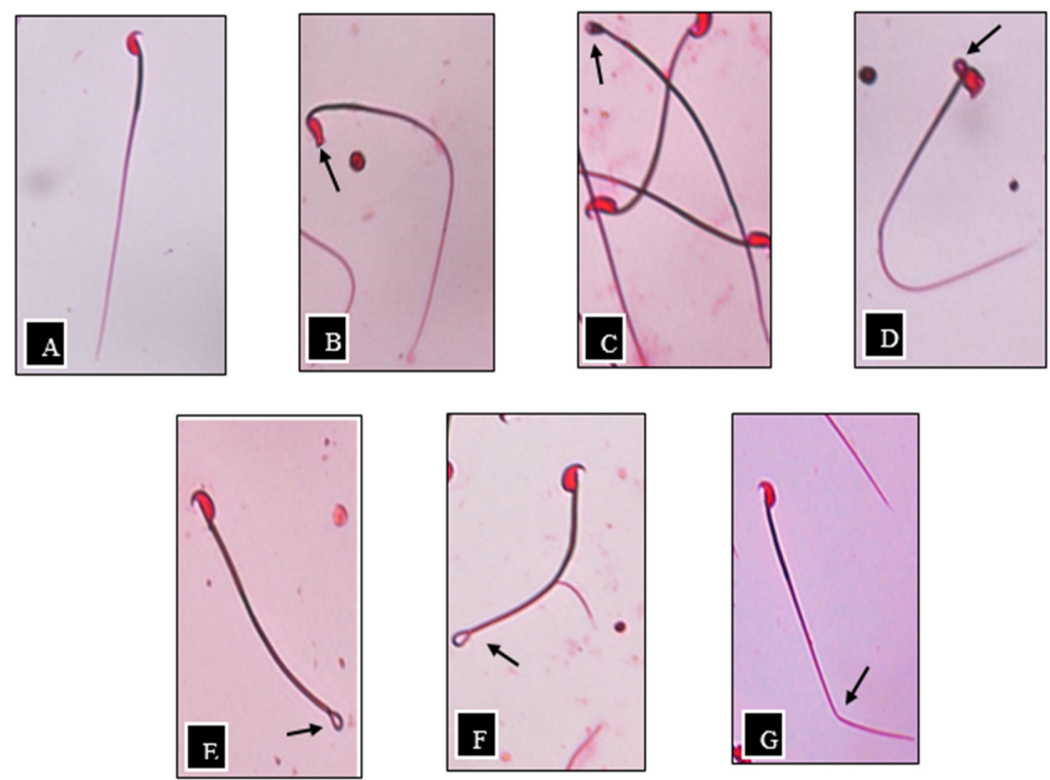

Fig. 1. Sperm morphology of ICR male mice, as indicated by eosin staining and observed using inverted microscope $(40 \times$ magnification), (A) Normal sperm, (B) No hook, (C) Pin head, (D) Bent head, (E) Coiled flagellum, (F) Hairpin loop, (G) Bent flagellum.

(Fig. 1).

Table 7 also showed that AEAM 100 and AEAM 150 resulted in higher sperm count compared to the control but there was no significant difference being recorded. Basically, the function of mitochondria for ATP production is extremely important to obtain optimum capacity of sperm motility specifically at the tail structure. ${ }^{55}$ ATP is the main source of energy in sperm motility that became the most important sperm parameter for fertility investigation. ${ }^{56}$ Motility of sperm is one of the critical state in allowing the sperm to ascend the female reproductive tract and also it is essential to achieve fertilization. ${ }^{57}$

Thus, the present finding discovered that the percentage of sperm motility is significantly higher for the treated groups, AEAM 100, 150, 200 and 1000 as compared to the control group (Table 5). Therefore, it is confirmed that the administration of AEAM which possess antioxidant properties is very helpful in fighting the sperm cell damage that caused by reactive oxygen species (ROS) and thus leads to increase sperm motility and reduce sperm abnormality in treated mice. This finding also in agreement with the previous study ${ }^{58}$, they also added that the antioxidant compounds from the plant derived can also enhance fertilization process for several folds and resulted in reducing men infertility problem. In maintaining the normal cell function, antioxidants compounds are vital to scavenge and suppress the ROS formation, or oppose their actions..$^{53,59}$ Moreover, no abnormal signs were observed in both toxicity studies except mild sedative effect that appeared after oral administration of AEAM in all treated groups especially in the treated mice that received higher doses of AEAM. 
In conclusion, the present study revealed that a single dose of AEAM up to a dose of $2000 \mathrm{mg} / \mathrm{kg}$ body weight was found to be safe when tested in ICR male mice. In sub-acute toxicity study, the administration of AEAM up to a dose of $500 \mathrm{mg} / \mathrm{kg}$ body weight did not cause any adverse effects or lethality to the treated mice. However, the slight reduction in body weight in all treated mice was observed starting from day 7 until day 14 when compared to their initial body weight on day 0 . Surprisingly, the slight increment in their body weight on day 21 was observed except in the treated mice that received AEAM 1000. The results also demonstrate that AEAM has a therapeutic potential in improving sperm quality in mice and can be one of the alternative medicine to combat infertility problem. Therefore, further studies are still needed for a better understanding of the toxicity effects that produced by administration of AEAM in the future.

\section{Acknowledgments}

The authors are grateful to the Al-Hilmi Group of Companies for awarding research grant, 2015-0170-10229 for the financial support and also the Biology Department, Faculty of Science and Mathematics, University Pendidikan Sultan Idris for providing facilities to conduct this research.

\section{References}

(1) Redzuan Nul Hakim, A. R.; Muhammad Lokman, M. I.; Afzan M. Y.; Azantee Yazmie A. W.; Hussin, M.; Roszaman, R. J. Biotechnol. Strategic Health Res. 2017, 1, 17-23.

(2) Parandin, R.; Yousofvand, N.; Ghorbani, R. Iran J. Reprod. Med. 2012, 10, 355-362

(3) Agnes, V. F.; Akbarsha, M. A. Food Chem. Toxicol. 2003, 41, 119130.

(4) Chauhan, N. S.; Dixit, V. K. Int. J. Appl. Res. Nat. Prod. 2008, l, 26-31.

(5) Ekaluo, U. B.; Erem, F. A.; Omeje, I. S.; Ikpeme, E. V.; Ibiang, Y. B.; Ekanem, B. E. IOSR J. Environ. Sci. Toxicol. Food Technol. 2013, 3, 21-23.

(6) Wahab, N. A.; Mokhtar, N. M.; Halim, W. N.; Das, S. Clinics 2010, 65, 93-98.

(7) Mahmoud, A. S. F.; Noor, M. M. AIP Conf. Proc. 2013, 1571, 227 233.

(8) Nor-Raidah, R.; Mahanem, M. N. Malays. Appl. Biol. 2015, 44, 125-131.

(9) Hakim, P.; Sani , H. A.; Noor, M. M. Malaysian J. Biochem. Mol. Biol. 2008, 16, 10-14.

(10) Giribabu, N.; Kumar, K. E.; Rekha, S. S.; Muniandy, S.; Salleh, N. BMC Complement. Altern. Med. 2014, 14, 291.

(11) Parhizkar, S.; Yusoff, M. J.; Dollah, M. A. Adv. Pharm. Bull. 2013, 3, 345-352.

(12) Idris, M. H.; Budin, S. B.; Osman, M.; Mohamed, J. EXCLI J. 2012, 11, 659-669.

(13) Fatmawati.; Hidayat, R. Eur. J. Pharm. Med. Res. 2016, 3, 46-49.
(14) Bahrani, H.; Mohamad, J.; Paydar, M. J.; Rothan, H. A. Curr. Alzheimer Res. 2014, 11, 206-214.

(15) Hara, H.; Ise, Y.; Morimoto, N.; Shimazawa, M.; Ichihashi, K.; Ohyama, M.; Iinuma. M. Biosci. Biotechnol. Biochem. 2008, 72, 335-345.

(16) Kakino, M.; Tazawa, S.; Maruyama, H.; Tsuruma, K.; Araki, Y.; Shimazawa, M.; Hara, H. BMC Complement. Altern. Med. 2010, 10, 68.

(17) Zhou, M.; Wang, H.; Suolangiiba; Kou, J.; Yu, B. J. Ethnopharmacol. 2008, $117,345-350$.

(18) Dash, M.; Patra, J. K.; Panda, P. P. Afr. J. Biotechnol. 2008, 7, 3531-3534.

(19) Begum, Y. Pharma Tutor 2016, 4, 47-50.

(20) Pranakhon, R.; Pannangpetch, P.; Aromdee, C. Songklanakarin. J. Sci. Technol. 2011, 33, 405-410.

(21) Ukwuani, A. N.; Abubakar, M. G.; Hassan, S. W.; Agaie, B. M. Int. J. Pharm. Sci. Drug Res. 2012, 4, 245-249.

(22) Ali Khairullah, Z.; Hazilawati, H.; Hutheyfa, S.; Mohd Rosly, S.; Sithambaram, S.; Hemn Hasan, O. Asian J. Pharm. Clin. Res. 2015, 8, 400-408.

(23) Anisuzzaman, A. S. M.; Sugimoto, N.; Sadik, G.; Gafur, M. A. Pak. J. Biol. Sci. 2001, 4, 1012-1015.

(24) Kazmi, I.; Afzal, M.; Rahman, M.; Gupta, G.; Anwar, F. Asian Pac. J. Trop. Dis. 2012, 2, S841-S845.

(25) Carro-Juárez, M.; Franco, M. Á.; Rodriguez-Peña, Mde. L. J. Evid. Based Complement. Altern. Med. 2014, 19, 43-50.

(26) Wil, N. N. A. N.; Omar, N. M.; Ibrahim, N. A.; Tajuddin, S. N. J. Chem. Pharm. Res. 2014, 6, 688-693.

(27) Ghan, S. Y.; Chin, J. H.; Thoo, Y. Y.; Yim, H. S.; Ho, C. W. Int. J. Pharm. Sci. Res. 2016, 7, 1456-1461.

(28) Veeresh; Kumar, P.; Gupta, V. R. M. J. Phytopharmacol. 2017, 6, 178-182.

(29) OECD/OCDE, OECD Guidelines for the testing of chemicals 407. 2008.

(30) Erhirhie, E. O.; Ekene, N. E.; Ajaghaku, D. L. J. Nat. Sci. Res. 2014, 4, 100-106.

(31) Ali, R.; Ali, R.; Jaimini, A.; Nishad, D. K.; Mittal, G.; Chaurasia, O. P.; Kumar, R.; Bhatnagar, A.; Singh, S. B. Indian J. Pharmacol. 2012, 44, 504-508.

(32) Arsad, S. S.; Esa, N. M.; Hamzah, H.; Othman, F. J. Med. Plant Res. 2013, 7, 3030-3040

(33) Aniagu, S. O.; Nwinyi, F. C.; Akumka, D. D.; Ajoku, G. A.; Dzarma, S.; Izebe, K. S.; Ditse, M.; Nwaneri, P. E. C.; Wambebe, C.; Gamaniel, K. Afr. J. Biotechnol. 2005, 4, 72-78.

(34) Ilgın, S.; Aydoğan-Kılıç, G.; Baysal, M.; Kılıç, V; Ardıç, M.; Uçarcan, Ş.; Atlı, Ö. Oxid. Med. Cell. Longev. 2018, 2018, 7196142.

(35) Sönmez, M.; Türk, G.; Yüce, A. Theriogenology 2005, 63, 20632072.

(36) El-Kashoury, A. A.; Salama, A. F.; Selim, A. I.; Mohamed, R. A. Life Sci. J. 2010, 7, 5-19.

(37) Akunna, G. G.; Saalu, L. C.; Ogunlade, B.; Ojewale, A. O.; Enye, L. A. Am. J. Res. Commun. 2013, $1,123-142$

(38) Sakr, S. A.; Zowail, M. E.; Marzouk, A. M. Anat. Cell. Biol. 2014, $47,171-179$.

(39) Takeda, N.; Yoshinaga, K.; Furushima, K.; Takamune, K.; Li, Z.; Abe, S. I.; Aizawa, S.; Yamamura, K. Sci. Rep. 2016, 6, 27409.

(40) Lucio, R. A.; Tlachi-López, J. L.; Eguibar, J. R.; Ågmo, A. Physiol. Behav. 2013, 110, 73-79.

(41) Neergheen-Bhujun, V. S. Biomed. Res. Int. 2013. 2013, 804086

(42) Pingale, S. S.; Ganpat, M. A.; Gawali, S. Int. Res. J. Pharm. 2011, 2, 263-266.

(43) Ellacott, K. L.; Morton, G. J.; Woods, S. C.; Tso, P.; Schwartz, M. W. Cell. Metab. 2010, 12, 10-17.

(44) Sattayasai, J.; Bantadkit, J.; Aromdee, C.; Lattmann, E.; Airarat, W. J. Ayurveda Integr. Med. 2012, 3, 175-179. 
(45) Sanyal, S.; Maity, P.; Pradhan, A.; Bepari, M.; Dey, S. K.; Roy, T.; Choudhury, S. T. Toxicol. Forensic Med. 2016, 1, 54-64.

(46) Sharif, H. B.; Mukhtar, M. D.; Mustapha, Y.; Baba, G.; Lawal, A. O. Adv. Pharm, 2015. 2015, 1-9.

(47) Shahraki, M. R.; Shahraki, S.; Arab, M. R.; Shahrakipour, M. Zahedan J. Res. Med. Sci. 2015, 17, 42-46.

(48) Chen, D.; Bi, D.; Song, Y. L.; Tu, P. F. Chin. J. Nat. Med. 2012, 10, 287-291.

(49) Yang, L.; Qiao, L.; Xie, D.; Yuan, Y.; Chen, N.; Dai, J.; Guo, S. Phytochemistry 2012, 76, 92-97.

(50) Peng, K.; Mei, W. L.; Zhao, Y. X.; Tan, L. H.; Wang, Q. H.; Dai, H. F. J. Asian Nat. Prod. Res. 2011, 13, 951-955.

(51) Chen, H. Q.; Wei, J. H.; Yang, J. S.; Zhang, Z.; Yang, Y.; Gao, Z. H.; Sui, C.; Gong, B. Chem. Biodivers. 2012, 9, 236-250.

(52) Khalil, A. S.; Rahim, A. A.; Taha, K. K.; Abdallah, K. B. J Appl. Indus. Sci. 2013, 1, 78-88.

(53) Sheweita, S. A.; Tilmisany, A. M.; Al-Sawaf, H. Curr. Drug
Metab. 2005, 6, 495-501.

(54) Thakur, M.; Chauhan, N. S.; Bhargava, S.; Dixit, V. K. Arch. Sex. Behav. 2009, 38 1009-1015.

(55) Cheah, Y.; Yang, W. Adv. Biosci. Biotechnol. 2011, 2, 182-197.

(56) Adenubi, O. T.; Raji, Y.; Awe, E. O.; Makinde, J. M. Sci. World J. 2010, 5, 1-6.

(57) Yousef, M. I.; Salama, A. F. Food Chem. Toxicol. 2009, 47, 11681175.

(58) Pratap, S. A.; Rajender, S. Front. Biosci. 2012, 1, 167-180.

(59) Agarwal, A., Sekhon, L. H. Hum. Fertil. 2010, 13, 217-225.

Received November 18, 2018

Revised December 18, 2018

Accepted December 18, 2018 